\title{
Synthesis and Antimicrobial Activities of Novel Palladium (II) Complexes of Active Schiff's Base Ligand Derived from 5-Bromo Isatin
}

\author{
Ashok N. Patange*, Uttam M. Yadav, Pratik A. Desai, Pravin U. Singare \\ Department of Chemistry, Bhavan's College, Munshi Nagar, Andheri (West), Mumbai 400058, \\ India \\ E-mail address: ashokpatange78@gmail.com, pravinsingare@gmail.com
}

\begin{abstract}
Keywords: Schiff's base; Semicarbazone; Thiosemicarbazone; 5-bromo Isatin; Bacillus pumilus ; Micrococcus Lutes; E. Coli; Salmonella abony
\end{abstract}

\begin{abstract}
This paper presents the synthesis and antimicrobial studies of Palladium (II) complexes of ThioSemicarbazone $\mathrm{Pd}\left(\mathrm{L}_{1} \mathrm{H}\right)_{2} \mathrm{Cl}_{2}$ and Semicarbazone $\mathrm{Pd}\left(\mathrm{L}_{2} \mathrm{H}\right)_{2} \mathrm{Cl}_{2}$ derived from 5Bromo Isatin. All complexes reported here had been characterised by ${ }^{1} \mathrm{H}$ NMR and IR spectral studies .the complexes are diamagnetic in nature and showing square planner geometry. The IR spectral data reveals that both the Schiff's bases behave as bidentate ligands and are co-ordinated to $\mathrm{Pd}$ (II) metal through the sulfur and hydrogenic nitrogen atom. All the new synthesized compounds were screened for antibacterial activity against four of the test organisms like Bacillus pumilus, Micrococcus Lutes, E.coli, Salmonella abony.
\end{abstract}

\section{INTRODUCTION}

Several studies [1-2] have shown a growing interest in transition metal complexes of Schiff base ligands in past few decades. The introduction of metal ion and metal compound to the biological system for therapeutic purpose occupies an important part. Research has shown that various co-ordination compounds have found their application in the treatment of various diseases. Interest in medicinal chemistry has been stimulated by improved methods of biological test procedures and clinical diagnosis. It attempts to establish relationship between chemical structure and biological activity and links biodynamic behaviour to the chemical reactivity and physical properties of therapeutic agents. Medicinal chemistry involves the isolation, characterization, elucidation of structure and synthesis of compounds [3-12] which can be used as medicine for the prevention of disease. Co-ordination compounds are compounds containing one or more coordinate bonds, which is a link between a pair of electrons in which both electrons are donated by one of the atoms. The metal complexes of semicarbzones and thiosemicarbazone [13-17] have aroused considerable interest in view of their industrial and biological importance. Many of these compounds possess a wide spectrum of medicinal properties. Thiosemicarbazides and thiosemicrbazones react as chelating agents with transition metals ions by bonding through the sulfur and hydrogenic nitrogen atom. In the present investigation we have synthesized and characterize some new biologically active Schiff's base complexes of palladium metals in order to evaluate their antibacterial activity.

\section{EXPERIMENTAL}

\subsection{Preparation of Chalcones}

In the three necked round bottom flask a mixture of $0.1 \mathrm{M}$ 5-Bromo Istain and $50 \mathrm{~mL}$ ethanol were taken and stirred for $1 \mathrm{~h} \mathrm{[18-20]}$. Meanwhile the $25 \mathrm{~mL}$ solution of $20 \%$ caustic soda mixed with $0.1 \mathrm{~mol}$ aromatic ketone was prepared. Above solution was added slowly to ethanolic solution of bromoisatin maintaining temperature of $15-20{ }^{\circ} \mathrm{C}$. Then the reaction mass was refluxed on water bath for 2-3 $\mathrm{h}$. The progress of reaction was monitored by Thin Layer Chromatography (TLC) method. After completion of the reaction, the mixture was cooled on ice salt bath. It was filtered and washed with water and the resulting chalcone re-crystallized with ethyl acetate. 


\subsection{Preparation of Preparation of Ligands}

The ligands of hydrazinecarbothiamide $\left(\mathrm{L}_{1} \mathrm{H}\right)$ of 5-Bromo Isatinand hydrazine-carboxamide $\left(\mathrm{L}_{2} \mathrm{H}\right)$ of 5-Bromo Isatin are prepared as follows:

2.2.1 Preparation of hydrazinecarbothiamide $\left(L_{1} H\right)$ of 5-bromoindolinedione: The $0.01 \mathrm{~mol}$ of chalcone [21-28] was added to $25 \mathrm{~mL}$ of THF and 0.012 mol thiosemicarbazide was added along with $5 \mathrm{~g}$ of sodium acetate. The reaction mixture was then refluxed on water bath for 2-3 $\mathrm{h}$. The progress of reaction was monitored by TLC method. After completion of the reaction, the mixture was cooled on ice-salt mixture; it was then filtered and re-crystallized with alcohol.

2.2.2 Preparation of hydrazine-carboxamide $\left(L_{2} H\right)$ of 5-bromoindolinedione: The mixture of 0.01 mol chalcone and $0.012 \mathrm{~mol}$ semicarbazide hydrochloride was added to $50 \mathrm{~mL}$ of THF. To that $5 \mathrm{~g}$ of sodium acetate was added. The reaction mixture was refluxed on water bath for 2-3 $\mathrm{h}$. The progress of reaction was monitored by TLC method. After completion of the reaction, the reaction mixture was cooled, filtered and the product obtained was re-crystallized by alcohol. The crystalized powder was further subjected to Silica gel column chromatograpphy (2\% EtoAcHexane) to get purified product.

\subsection{Preparation of $\left[\mathrm{Pd}(\mathrm{LH})_{2}\right] \mathrm{Cl}_{2}$ complexes}

$0.001 \mathrm{~mol} \mathrm{PdCl}_{2}$ was added to $0.002 \mathrm{~mol}$ ethanolic [29-31] solution of ligand. The reaction mixture was than heated under reflux for about $6 \mathrm{~h}$ in presence of few drops of concentrated $\mathrm{HCl}$. The reaction mixture was than cooled and filtered. The crystal obtained were washed several times with ice cold alcohol and dried in vacuum.

2.4 Preparation of $\left[\mathbf{P d}(\mathbf{L})_{2}\right]$ complexes: The 0.001 mol ethanolic solution of $\mathrm{PdCl}_{2}$ was mixed with an 0.002 mol ethanolic solution of ligands [32] in 1:2 molar ratio. $\mathrm{NH}_{4} \mathrm{OH}$ was added drop wise to reaction mixture until it was weakly alkaline ( $\mathrm{pH} 8.0)$. The mixture was then stirred for 2-3 $\mathrm{h}$ and heated at $40{ }^{\circ} \mathrm{C}$ for 45 minutes. On cooling the separated complexes were filtered and washed several times with alcohol and dried in vacuum.

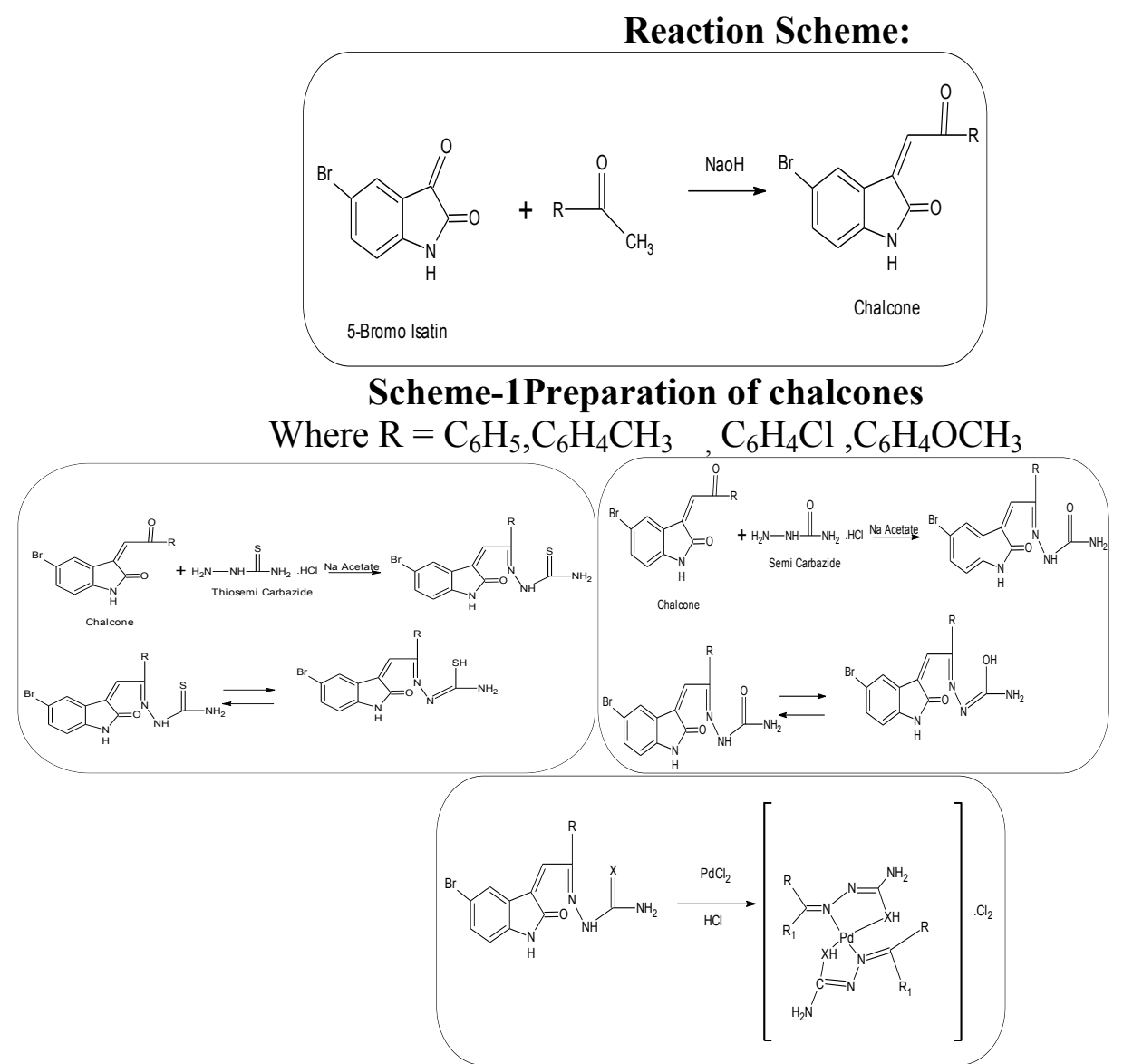

Scheme-2 Preparation of Ligands $\left(\mathrm{L}_{1} H\right)$ and $\left(\mathrm{L}_{2} \mathrm{H}\right)$ 


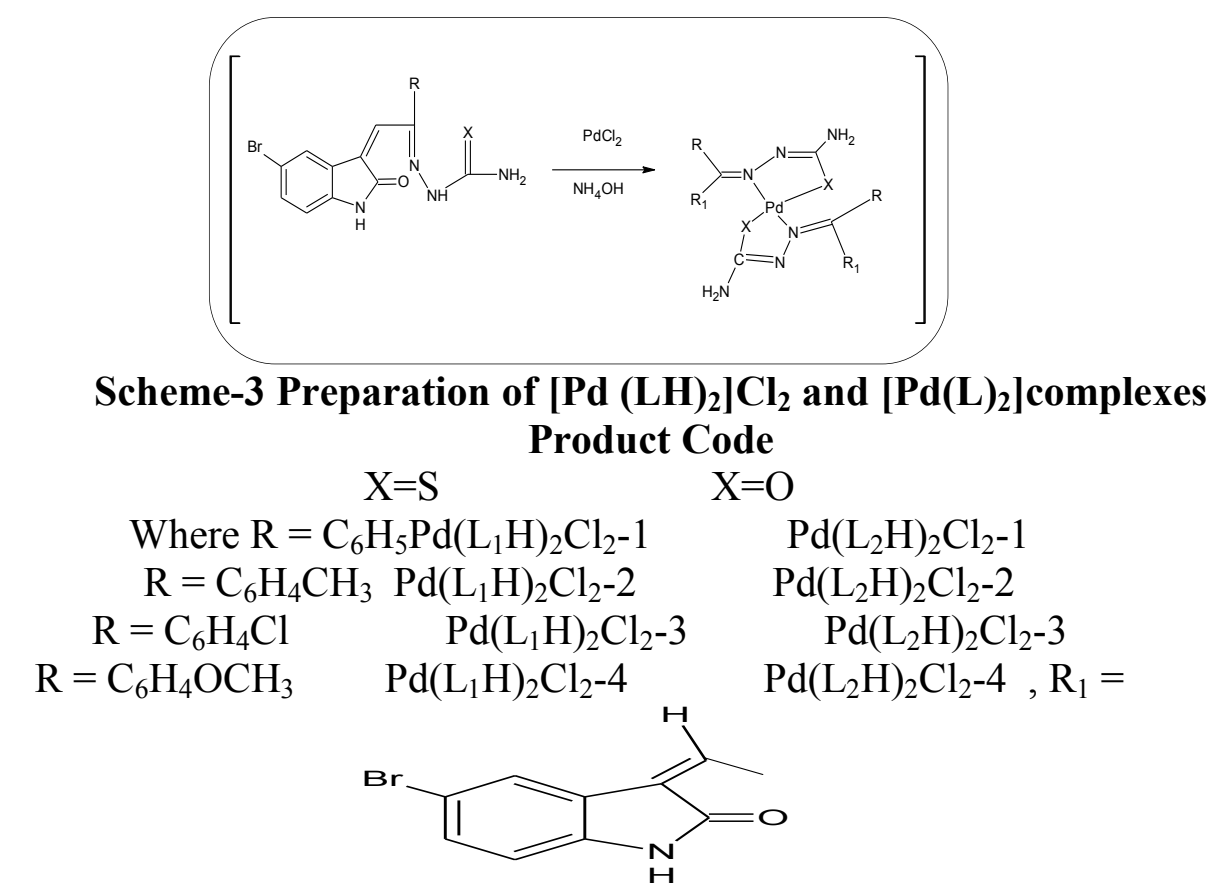

For the entire experimental work the chemicals used were of analytical reagent (A.R.) grade purchased from S.D Fine chemicals (Mumbai) and were used after purification.

\section{RESULT AND DISCUSSION}

The ligand $\left(\mathrm{L}_{1} \mathrm{H}\right)$ : In the IR spectrum [33] of ligand $\left(\mathrm{L}_{1} \mathrm{H}\right)$ bands corresponding to $-\mathrm{NH}_{2}$ and -NH groups appeared at 3463 and $3263 \mathrm{~cm}^{-1}$ respectively.thebands corresponding to ${ }_{v}(\mathrm{C}=\mathrm{S})$ and ${ }_{v}(\mathrm{C}=\mathrm{N})$ groups appeared at 818 and $1587 \mathrm{~cm}^{-1}$. In the ligand $\left(\mathrm{L}_{2} \mathrm{H}\right)$ : the band corresponding ${ }_{\mathrm{v}}(\mathrm{C}=\mathrm{O})$ appeared at $1711 \mathrm{~cm}^{-1}$. On complexation the bands corresponding to ${ }_{v}(C=N)$ and ${ }_{v}(C=S)$ (in case of thiosemicarbazone) are shifted towards lower side $\left(\mathrm{ca} .20-30 \mathrm{~cm}^{-1}\right)$. This suggest that the ligand acts as a bidentate chelating agent coordinating through nitrogen of ${ }_{\mathrm{v}}(\mathrm{C}=\mathrm{N})$ group and sulphur of ${ }_{\mathrm{v}}(\mathrm{C}=$ S) group. In case of semicarbazone the bands corresponding to ${ }_{v}(C=N)[34]$ and ${ }_{v}(C=O)$ are shifted towards lower side (ca.20-30 $\mathrm{cm}^{-1}$ ) suggest that the ligand acts as a bidentate chelating agent coordinating through nitrogen of ${ }_{v}(C=N)$ group and oxygen of ${ }_{v}(C=O)$ group. In the ${ }^{1} \mathrm{H} N M R$ spectrum of ligands \& complexes the most common NMR multiplets for Aromatic rings protons are found to be resonating around $\delta 7.5-\delta 8.4$ whereas the broad singlet for $>\mathrm{NH} \&-\mathrm{NH}_{2}$ group protons appeared around $\delta 3.3-\delta 3.6$. A sharp singlet peak for olefinic protons $(>\mathrm{C}=\mathrm{C}-\mathrm{H})$ group in ligands as well as in the complexes are observed in the range of $\delta 7.1-\delta 7.4$. The distinguishing singlet peak around $\delta 9.0$ in ligands are due to $(>\mathrm{C}=\mathrm{N}$-group) azomethine protons but in the complexes this singlet was shifted to downfield $\&$ appears at $\delta 9.3$ due to co-ordination thorough $>\mathrm{C}=\mathrm{N}$-group.

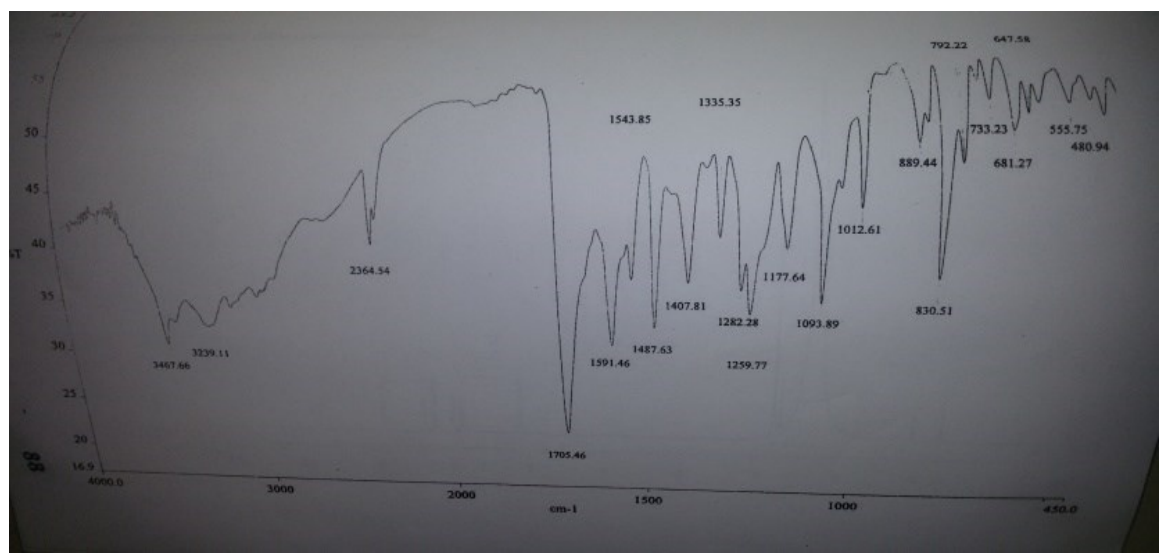

Figure 1. IR spectrum of Ligands $L_{2} H$ 


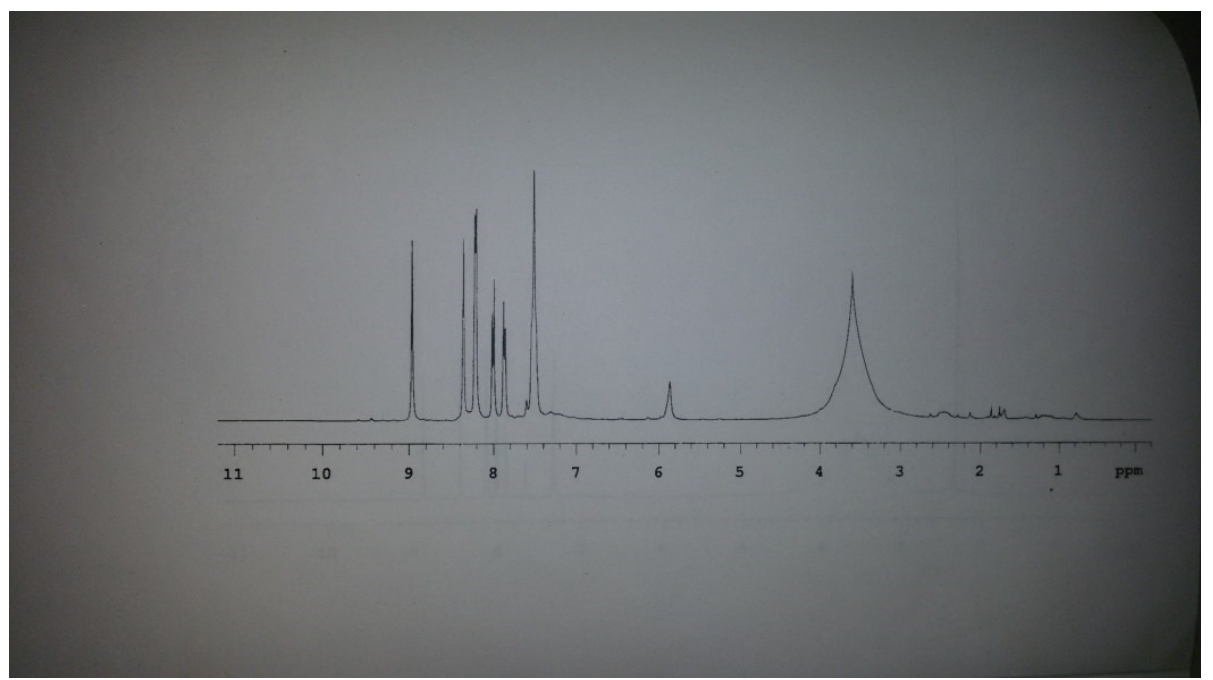

Figure 2. NMR spectrum of Ligands $\mathrm{L}_{2} \mathrm{H}$

${ }^{1}$ HNMR (400 MHz, $\mathbf{C D C l}_{3}$ ) $\boldsymbol{\delta}_{\text {ppm }}$ of Chalcone:- $\delta 3.6 \mathrm{Brs} \mathrm{S}(>\mathrm{NH}), \delta 7.5 \mathrm{~S}$ (1H olefinic proton), 87.2-8.2 $\mathrm{M}(7 \mathrm{H}$ aromatic ring proton).

${ }^{1} \mathrm{HNMR}\left(400 \mathrm{MHz}, \mathrm{CDCl}_{3}\right) \boldsymbol{\delta}_{\mathrm{ppm}}$ of Lingand( $\left.\mathrm{L}_{1} \mathrm{H}\right)$ :- $\delta 3.5 \mathrm{Brs} \mathrm{S} 4 \mathrm{H}\left(>\mathrm{NH} \& \mathrm{NH}_{2}\right), \delta$ 7.6 S (1H olefinic proton), $\delta 7.1-9.1 \mathrm{M}$ (7H aromatic ring proton).

${ }^{1} \mathrm{HNMR}\left(400 \mathrm{MHz}, \mathrm{CDCl}_{3}\right) \boldsymbol{\delta}_{\mathrm{ppm}}$ of complexes [Pd $\left.\left(\mathrm{L}_{1} \mathrm{H}\right)_{2}\right] \mathrm{Cl}_{2}: \delta 3.5 \mathrm{Brs} \mathrm{S} 4 \mathrm{H}\left(>\mathrm{NH} \& \mathrm{NH}_{2}\right)$, $\delta 7.6 \mathrm{~S}(1 \mathrm{H}$ olefinic proton), $\delta 7.2-8.8 \mathrm{M}(7 \mathrm{H}$ aromatic ring proton). $\delta 9.3 \mathrm{~S} 1 \mathrm{H}(=\mathrm{N}-\mathrm{H}$, azomethine)

\subsection{ANTIBACTERIAL ACTIVITY}

All the new synthesized compounds were screened for antibacterial activity [35] against four of the test organism like Bacilluspumilus, Micrococcus Lutes, E. coli, Salmonella abony. For this screening, plate diffusion method was used [36].

\subsection{Plate Diffusion Method}

The compound was weighed $(25 \mathrm{mg})$ and dissolved in methanol/DMF and phosphate buffer (2:8). The compounds were taken at $1000 \mathrm{mcg} / \mathrm{mL}$ per hole of petridish containing M.agar medium or antibiotic assay medium No.11. The hole in the medium should be more than $2.5 \mathrm{~mm}$ and $7.8 \mathrm{~mm}$ diameter. These holes in the petridish were then filled with antibacterial solution. The plates were then placed in refrigerator for $10{ }^{\circ} \mathrm{C}$, at $15{ }^{\circ} \mathrm{C}$ for diffusion of the compounds and then incubated for $24 \mathrm{~h}$ at $37^{\circ} \mathrm{C}$. After the incubation period was over the zone of inhibitions were measured in $\mathrm{mm}$ as distance from source and are reported. Bacterial activity of the ligand and their metal complexes are recorded Table 1 and 2 against Pathogenic bacteria. The free ligand and their respective metal chelates were screened against gram positive bacteria like Bacillus Pumillius and Micrococcus; gram negative bacteria like E.Colli and Salmonella to evaluate their potential as antimicrobial agents. The results are quite promising. The antibacterial data reveals $[37,38]$ that complexes are ligands. It is also noted that sulphur containing ligand as well as their complexes are more active than their oxygen containing counterpart.
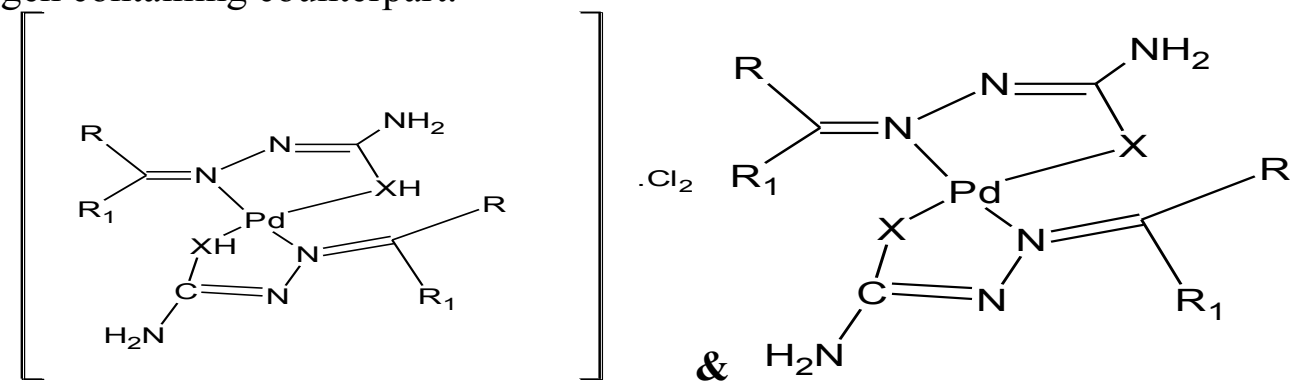

$\left[\mathrm{Pd}(\mathrm{LH})_{2}\right] \mathrm{Cl}_{2}$ and $\left[\mathrm{Pd}(\mathrm{L})_{2}\right]$ complexes 
Table 1. Antibacterial activity of the ligand and their Pd-metal complexes

\begin{tabular}{|c|c|c|c|c|c|c|}
\hline $\begin{array}{c}\text { Sr. } \\
\text { No }\end{array}$ & $\mathbf{R}$ & $\mathbf{X}$ & $\begin{array}{c}\text { Bacillus } \\
\text { Pumillius }\end{array}$ & Micrococcus & E.colli & Salmonella \\
\hline 1 & $\mathrm{Pd}\left(\mathrm{L}_{1} \mathrm{H}\right)_{2} \mathrm{Cl}_{2}-1$ & $\mathrm{~S}$ & 4.30 & 3.10 & 3.01 & 2.10 \\
\hline 2 & $\mathrm{Pd}\left(\mathrm{L}_{1} \mathrm{H}\right)_{2} \mathrm{Cl}_{2}-2$ & $\mathrm{~S}$ & 4.80 & 3.60 & 3.30 & 3.40 \\
\hline 3 & $\mathrm{Pd}\left(\mathrm{L}_{1} \mathrm{H}\right)_{2} \mathrm{Cl}_{2}-3$ & $\mathrm{~S}$ & 5.20 & 2.80 & 3.95 & 2.60 \\
\hline 4 & $\mathrm{Pd}\left(\mathrm{L}_{1} \mathrm{H}\right)_{2} \mathrm{Cl}_{2}-4$ & $\mathrm{~S}$ & 1.40 & 1.10 & 0.30 & 0.40 \\
\hline 5 & $\mathrm{Pd}\left(\mathrm{L}_{2} \mathrm{H}\right)_{2} \mathrm{Cl}_{2}-1$ & $\mathrm{O}$ & 3.90 & 3.85 & 2.35 & 1.70 \\
\hline 6 & $\mathrm{Pd}\left(\mathrm{L}_{2} \mathrm{H}\right)_{2} \mathrm{Cl}_{2}-2$ & $\mathrm{O}$ & 4.10 & 3.20 & 3.20 & 3.50 \\
\hline 7 & $\mathrm{Pd}\left(\mathrm{L}_{2} \mathrm{H}\right)_{2} \mathrm{Cl}_{2}-3$ & $\mathrm{O}$ & 4.85 & 3.90 & 3.65 & 3.90 \\
\hline 8 & $\mathrm{Pd}\left(\mathrm{L}_{2} \mathrm{H}\right)_{2} \mathrm{Cl}_{2}-4$ & $\mathrm{O}$ & 1.00 & - & 0.50 & - \\
\hline
\end{tabular}

Table 2. Antibacterial activity of the ligand and their Pd-metal complexes

\begin{tabular}{|c|c|c|c|c|c|c|}
\hline $\begin{array}{c}\text { Sr. } \\
\text { No }\end{array}$ & $\mathbf{R}$ & $\mathbf{X}$ & $\begin{array}{c}\text { Bacillus } \\
\text { Pumillius }\end{array}$ & Micrococcus & E.colli & Salmonella \\
\hline 1 & $\mathrm{Pd}\left(\mathrm{L}_{2}\right)_{2}-1$ & $\mathrm{~S}$ & 4.3 & 3.2 & 2.9 & - \\
\hline 2 & $\mathrm{Pd}\left(\mathrm{L}_{2}\right)_{2}-2$ & $\mathrm{~S}$ & 5.3 & 4.12 & 4.00 & 1.85 \\
\hline 3 & $\mathrm{Pd}\left(\mathrm{L}_{2}\right)_{2}-3$ & $\mathrm{~S}$ & 3.5 & 4.65 & 3.50 & 2.45 \\
\hline 4 & $\mathrm{Pd}\left(\mathrm{L}_{1}\right)_{2}-4$ & $\mathrm{~S}$ & 2.35 & 2.15 & 1.05 & 1.00 \\
\hline 5 & $\mathrm{Pd}\left(\mathrm{L}_{2}\right)_{2}-1$ & $\mathrm{O}$ & 3.80 & 3.25 & 2.25 & 3.40 \\
\hline 6 & $\mathrm{Pd}\left(\mathrm{L}_{2}\right)_{2}-2$ & $\mathrm{O}$ & 4.00 & 4.20 & 3.55 & 3.90 \\
\hline 7 & $\mathrm{Pd}\left(\mathrm{L}_{2}\right)_{2}-3$ & $\mathrm{O}$ & 4.95 & 3.85 & 3.15 & - \\
\hline 8 & $\mathrm{Pd}\left(\mathrm{L}_{2}\right)_{2}-4$ & $\mathrm{O}$ & 2.00 & 1.15 & - & 3.12 \\
\hline
\end{tabular}

\section{Acknowledgment}

The authors are thankful to Dr. V.G. Bhawe (Retired) Associate Professor Chemistry, Bhavan's College, Andheri, Mumbai for suggesting the research project and guidance during the entire research work.

\section{Reference}

[1] Rosenberg B., Vancamp L., Krigas T., Nature, 205 (1965) 698.

[2] Jakupec M., Keppler B.K., Sigel A., Sigel H. (Eds.), Metal Ions in Biological Systems, vol. 42, Marcel Dekker Inc. (2004).

[3] Butour S., Wimmer F., Wimmer F., Castan P., Chemico- Biological Interactions.,104 (1997)165.

[4] Bansal A. Singh R.V., Synth React Inorg Met-Org Chem., 31(2001)381.

[5] Laly S., Parameswaran G., Asian J. Chem., 5 (1993) 712.

[6] Somogyi L. Bull. Chem. Soc. Jpn., 74 (2001) 873.

[7] Da Silva J. F. M., Garden S. J., Pinto A. C., J. Braz. Chem. Soc., 12 (2001) 273.

[8] Chiyanzu I., Clarkson, C., Smith, P. J., Lehman, J., Gut, J., Rosenthal, P. J., Chibale, K., Bioorg. Med. Chem., 13 (2005)3249.

[9] Cerchiaro G., Micke G. A., Tavares, M. F. M., Ferriera, A. M. D. C., J. Mol.Catal. A: Chem., 221 (2004) 29.

[10] Varma R. S., Nobles W. L., J. Med. Chem., 10 (1967) 510.

[11] Pandeya S. N., Sriram D., Acta. Pharm. Turc., 40 (1998) 33. 
[12] Pandeya S. N., Sriram D., Nath G., De Clercq, E., Eur. J. Pharm. Sci., 9 (1999) 25.

[13] Teitz, Y., Ronen D., Vansover A., Stematsky T., Riggs J. L., Antiviral Res., 24 (1994) 305.

[14] Varma R.S., Pandeya R. K., Indian J. Pharm. Sci., 46 (1982) 132.

[15] Alam M., Younas M., Zafar M.A., Naeem, Pak. J.Sci. Ind. Res., 32 (1989) 246.

[16] Smolders R.R., Waefelaer A., Francart D., Ing. Chim. (Brussels), 64 (1982)5.

[17] Md. RabiulIsmlam, Mohammad Mohsin, Bangladesh. J .Pharmacol., 2 (2007) 7.

[18] Gustavson, J.Prakt. Chem., 37(1883) 108.

[19] Kohler T., Am. Chem. Soc., 24(1900) 385.

[20] Bhagat S., Sharma R., Sawant D.M., Sharma L., Journal of Molecular Catalysis A, 244 (2006) 20.

[21] Raval A.A., Shah N.M., J. Org. Chem., 22 (1975) 305.

[22] Dershowitz S., Prokauer S., J. Org. Chem., 26 (1961) 3595.

[23] Utale P.S., Raghuwanshi P.B., Doshi A.G., Asian. J Chem., 10 (1998) 597.

[24] Naik S.M., Naik H.B., Orient. J Chem., 14 (1998) 167.

[25] Sriram D., Yogeeswari P., Thirumurugan. R.S., Bioorg. Med. Chem. Lett., 14 (2004)3923.

[26] Singh H.P., Chauhan C.S., Pandeya S.N., Sharma C.S., Srivastava B., Singhal M., Der Pharm. Lett.,2 (2004) 460.

[27] Kovala-Demertzi D., Boccarelli A., Demertzis M.A., Coluccia M., Chemotherapy, 53 (2007)148.

[28] Khan S.A., Asiri A.M., Khan A.A., Khan K.A., Zayed M.A. M., Asian Journal of Chemistry, 25 (2013) 8643.

[29] Vinod K.S., Shipra S., Ankita S., Journal of Bioinorganic Chemistry Applications, 13 (2003)1.

[30] Turdor R., Aurelian G., Anca N., Rodica G., Oriental Journal of Chemistry, 52, (2007)782.

[31] Sulekh C., Umendra K., Verma H.S., Oriental Journal of Chemistry, 19 (2003) 355.

[32] Finch R.A., Liu M.C., Cory A.H., Cory J.G., Sartorelli A.C., Adv. Enzyme Regul., 39 (1999)3.

[33] Nutting C.M., van Herpen C.M.L., Miah A.B, Bhide S.A., Machiels J.P., Buter J., Kelly C., de Raucourt D., Harrington K. J. , Annals of Oncology, 20 (2009) 1275.

[34] Reddy V., Patil N., Patil B.R., J. Ind.Council Chem. 23 (2006) 1.

[35] Pandeya S.N., Mishra V., Singh P.N., Rupainwar D.C., Pharmacology, 37 (1998)17.

[36] Kavanagh F., (Editor) “Analytical Microbology” Academic Press Inc., New York (1963) p. 126.

[37] Leovac V.M., Jevtovic V.S., Jovanovic L.S., Bogdanovic S., Journal of Serbian Chemistry Society, 70 (2005) 394.

[38] Soumitra K.S., Om P.P., Bimal K.S., Journal of Transition Metal Chemistry, 23 (1998) 349. 